\title{
Here we go again: repeating implementation errors
}

\author{
Donald W Light
}

\begin{abstract}
Division of Social and Behavioral

Medicine,

University of

Medicine and

Dentistry of New

Jersey, Stratford,

NJ 08084, USA

Donald W Light

professor

lightd@mail.med. upenn.edu
\end{abstract}

BMJ 1999;319:616-8
The current reforms of the English NHS are being carefully watched in Eastern and Western Europe, parts of Latin America and Asia, and in former Commonwealth nations, because they aim to develop the concept of a "primary care led health service" more fully than has ever been realised before. Building on the transformation of the NHS from an administered to a commissioned service, the Labour reforms reject the costly, inequitable, and demoralising policies of competition and advocate sweeping changes based on cooperation. They call for bringing together formerly autonomous general practitioners into large groups, having them integrate their services with community health and social services, having them develop community-wide plans for health improvement, and devolving nearly the entire budget into their hands.

While these and other parts of Labour's grand plan are much better thought out than the Conservative reforms, some of the same mistakes of implementation are being repeated. As an excellent analysis of the current reforms warns, "If we have learned anything from the 1991 reforms ... it is that implementation is all."

\section{Too much too fast}

Good ideas and design can be ruined if the agents of implementation are overloaded or overwhelmed. The Conservatives, with their ill considered mandatory efficiency gains from secondary care, produced serious problems of morale and exhaustion that the Nuffield Trust has effectively documented, such as high turnover of staff, wastage, early retirement, sick absences, high stress, and the danger of serious clinical errors. ${ }^{2}$ If Labour does not slow its pace of implementation, it could create the same exhaustion and low morale in primary care that the Conservatives created in secondary care. Ironically, pressured implementation could crush the very boldness among general practice leaders on which the "new NHS" design depends. Re-engineering clinical care and integrating services take time and a great deal of effort. This is one of the seven lessons from effective commissioning groups, ${ }^{3}$ and recent reports from the field show how complex a job it is. ${ }^{4}$

\section{Too few incentives, too little risk}

Implementing the English white paper requires a lot of extra work, but why should nurses and general practitioners bother? They cannot get much (if any) extra pay, and they bear little financial risk for inefficiencies in the current arrangements or unnecessary services. Primary care groups, in theory, can keep any money they save, and each practice can keep up to $£ 45000$, but central costing and restrictions will prevent such savings from being made. The same mistakes were made with health authorities as commissioners in the 1990s, with tepid results. While Americans go danger-

\section{Summary points}

The NHS reforms are promising, but some mistakes of implementation by the last government are being repeated by this one

Primary care groups, like health authorities in the 1990 s, lack the resources, latitude, and incentives to commission effectively

Primary care groups will be taking on greater proportions of healthcare services but are not in line for greater proportions of the budget

The reforms embody conflicting models of governance-hierarchical control versus devolved commissioning-with doctors and nurses caught in the crossfire

Integrating primary, community, and social services and commissioning them effectively is the first order of business

Health authorities have major new responsibilities on top of the old ones and need to be strengthened

ously overboard with incentives and risks, another of the seven lessons for effective commissioning is that purchasers and providers must have some incentives and bear some risk for the decisions they make. ${ }^{3}$

Further, most healthcare costs and potential savings lie in specialty and hospital care. Therefore, cost effective commissioning will devolve more clinical work to the primary and community healthcare teams-more management of serious clinical problems, more post-hospital care, more work integrating care in the community, as well as more work to educate patients and prevent ill health. But it is quite difficult now for money to follow patients and work, even though in theory integrated budgets should enable primary care teams to have more of the budget as they do more of the work.

\section{Short-changing commissioners}

The new reforms, like the old ones, depend on better commissioning and management of services. Yet both are being underfunded. One of the Conservatives' great mistakes was to strengthen hospitals, by giving them trust status and highly paid executive teams, while they underpaid and underresourced health authorities as purchasers. ${ }^{6}$ This resulted in top talent migrating from the purchasing side to large hospitals and fiercely defending their grip on the healthcare budget. ${ }^{7}$ Yet those who hold budgets and purchase or commission are the key to any commissioning model of health care. 
Primary care commissioning is inherently a more costly design than a more centralised approach, such as the approach in the Scottish white paper. The hope is that general practitioners and nurses can save more than the extra cost by being smarter, tougher, and more creative commissioners than can managers in a health authority or health board. But an average allocation of $£ 3$ per head of population to do the job short-changes these new commissioners: evidence from the pilot schemes of total purchasing shows those teams needed an average of $£ 7$ per person, ${ }^{8}$ and even then most of the teams were struggling with their commissioning role. It is already evident that most of the primary care groups lack the time or resources to identify sources of waste and address them.

The government is also perpetuating the Conservatives' mistake of keeping health authorities weak through deeply ambivalent policies. It has assigned them seminal new roles at the same time as it has indicated they are to work themselves out of existence by developing successful primary care trusts. Health authorities have more to do than ever to make these reforms succeed, but not the resources. In what other industry would one meet, as I recently did, a director of finance responsible for a budget of $£ 300 \mathrm{~m}$ who has only one assistant and a part time secretary? He can do little more than keep up with the blizzard of directives from the centre and sign block contracts. But if the government does not resource commissioners well, why bother to commission at all? Weak or poorly informed commissioning leaves the healthcare system open to all sorts of manipulations and waste.

\section{Poor information and accountability}

As commissioners of integrated care with an integrated budget, general practitioners and nurses need to know how their patients are treated across all sectors and sites, at what cost, and to what effect. Otherwise they will be commissioning with blindfolds. Another great mistake by the Conservatives was to let hospital trusts collect what data they wanted, how they wanted, and to decide what they would share with their purchasers. Current implementation efforts recognise the central need for comparative clinical and financial data across sectors of care, and openly publishing costs is a substantial advance; but the problem seems greater than the efforts. Space precludes detailing the evidence that, even after eight years, many hospitals do not know their true costs, count staff as fixed costs, set marginal prices well above what international experience would estimate they should be, and overcharge. One business manager of a fundholding practice analysed a hospital bill for finished consultant episodes (FCEs) by patient and found 14 attributed to one patient. He also found a $£ 7000$ bill from a surgical department which turned out to be for an outpatient visit that the consultant did not attend. Yet health authorities, and now primary care groups, usually have no choice but to take the prices given them. Reference costing may help, but they may also lock in current inefficiencies and self protective accounting of practices. ${ }^{9}$

\section{Stifling commissioners with central control}

The core idea of commissioning, especially if devolved to general practitioners and nurses, is to empower those "close to the customer" to attain better service and quality at lower cost than corporate officers or governmental officials can from headquarters. ${ }^{10}$ This means that the central office sets general goals and provides the necessary resources (see above) but gives the leaders in the field the power and freedom to fulfil those goals. The problem, of course, is that local commissioning groups, or even health authorities, may be careless, make mistakes, or try something that fails. Devolved commissioning is a gamble that promises smarter, more effective solutions but will almost certainly produce its share of mistakes and failures. These in turn generate bad press, so the centre creates restrictions and requirements, performance indicators, and procedural rules that safeguard current institutions and arrangements, just as the Conservatives did. ${ }^{11-13}$ The result is conflicting paradigms of governance, with general practitioners and nurses feeling empowered by one and stifled by the other.

A principal goal of reforms and commissioning in nearly all countries is to break up and reconfigure the overhospitalised specialty services that built up during the 20th century, and the radical implication of commissioning for evidence based outcomes is that one wants to contract with specialists and let them subcontract for hospital services as they see fit. But the prime object of damage control from the centre is to protect the hospitals, and recent hospital mergers only increase their powers against effective commissioning.

When it comes to commissioning it is unclear to me what the government wants, though bad weather over the Atlantic may impair my vision. It is perpetuating the implementation error of keeping health authorities underresourced and then concluding that they are inept and clunky. That is why primary care commissioning is needed-to juice up all those doctors and nurses to do it right. But then they are given less than half the evidence based resources they need, and three times as many of their chief executives come from health authorities as from general practice fundholding and commissioning groups. ${ }^{14}$ And to make sure that the juiced up commissioning leaders don't upset currently wasteful arrangements, a raft of rules and requirements are put in place.

\section{Suggestions for success}

Some of issues I have raised are so basic that they cannot be addressed here and need full discussion. But one of the seven lessons for effective commissioning $^{3}$ is that primary care itself needs to be commissioned effectively. The capacities, clinical decisions, and inequities of primary care providers determine how equitable and cost effective the rest of the system is. Requiring small primary care teams to come together, overcome their many professional and cultural differences, and develop a collective responsibility for their own practices is an exciting part of the Labour reforms. Integrating them with community health and social services for health gain is a still 
larger agenda of great importance for nations everywhere. Getting this right seems to me the first order of business, together with developing an integrated information system on clinical performance and costs across all sectors.

This means that for several years the health authorities will do the major commissioning. They will also develop primary care groups, pull together health improvement plans, plan overall changes in services, nurture networks of diverse local agencies and organisations, and be accountable for evaluation. ${ }^{15}$ They need talented, well paid leadership teams with good technical resourcing. Beyond these basics lie the real savings through integrated pathways of care between secondary, primary, and community care. One key is to align primary care providers with consultants. Win-win contracts have been worked out in the United States that would reward both groups for developing ways to reduce the need for costly services.

Competing interests: None declared.
1 Klein RE, ed. Implementing the white paper: pitfalls and opportunities. London: King's Fund, 1998.

2 Williams S, Michie S, Pattani S. Improving the health of the NHS workforce. London: Nuffield Trust, 1998.

3 Light DW. Effective commissioming: lessons from purchasing in American managed care. London: Office of Health Economics, 1998.

4 Abbott S, Johnson L, Henwood M, Waddington E, Wistow G. A continuing challenge: evaluation of the implementation of continuing health care guidance. Leeds: Nuffield Institute for Health, 1998.

5 Regan E, Smith J, Shapiro J. First off the starting block: lessons from GP commissioning pilots for primary care groups. Birmingham: Health Services Management Unit, 1999.

6 Light DW. From managed competition to managed cooperation; theory and lessons from the British experience. Millbank O 1997;75:297-341.

7 Knowles D. A new style of leadership. In: Klein RE, ed. Implementing the white paper:pitfalls and opportunities. London: King's Fund, 1998:74-84.

8 Mays N, Mulligan J-A. Total purchasing. In: LeGrand J, Mays N, Mulligan J-A, eds. Learning from the NHS internal market. London: King's Fund, 1998:84-99.

9 NHS Executive. The new NHS 1998 reference costs. Leeds: NHS Executive, 1998.

10 Hunter D. Dangers of target practice. Health Serv J 1999 June 24:16-17.

11 Light DW. Observations on the NHS reforms: an American perspective. BMJ 1991;303:568-70.

12 Dawson D. Regulating competition in the NHS. York: Centre for Health Economics, 1995.

13 Light DW. Is NHS purchasing serious? An American perspective. BMJ 1998;316:217-20.

14 Gould M, Crail M. Quarter of PCGs start without a chief executive. Health Serv J 1999 April 1:2-3.

15 Higgins J. HAs been? Health Serv 1999 Jan 28:22-3.
Two blocks along the left bank of the Seine from the Eiffel Tower is the Rue du Docteur Finlay. Eponymous streets abound in France, but most are dedicated to French notables, and rarely if ever fictional ones. Spring to mind though he may, therefore, we are not dealing here with the junior partner at Tannochbrae.*

Instead, the doctor in question is Carlos Juan Finlay. The street sign describes Finlay as "Médecin et chercheur cubain,

1833-1915." This is too brief a description to do justice either to Finlay's cosmopolitan background or his universal influence. For Finlay was of Scottish, French, and Irish stock, and is generally credited with having been first to propose that yellow fever was spread by mosquitoes. He suggested, in 1881, that this mortal disease, so prevalent in the cities of South and Central America and the southern United States, as well as in west Africa, was spread by Stegomyia fasciata (now known as Aedes aegypti).

Later in the 1880s Finlay did experiments in which volunteers were exposed to mosquitoes that had fed on yellow fever patients. His purpose was to discover whether transmission might occur by this route and whether, due to attenuation, those so exposed might have been safely immunised. Better known successors of Finlay, such as Walter Reed, went on to confirm insect transmission of yellow fever and a little later, in India, Ronald Ross showed that anophelene mosquitoes transmitted malaria Ross's work, unlike Finlay's, attracted a Nobel Prize.

The next generation of researchers demonstrated that Aedes aegypti was also a frequent vector of dengue, and a third generation, in the shape of Lloyd, Theiler, and Smith, attenuated the yellow fever virus by multiple passage in chick embryos to prepare the yellow fever vaccine, $17 \mathrm{D}$, that is still in universal use 60 years later.

The comparative neglect of Carlos Finlay is probably explained by the fact that no one country could legitimately lay claim to him. His father, also a doctor, had been born in Hull of Scottish parents and had trained in Rouen under the famous Dr Flaubert (father of the yet more distinguished Gustave). Finlay's mother was French. He himself was born in Camaguey, Cuba, but was schooled at French lycées, trained in medicine at the Jefferson College, Philadelphia, and practised most of his life in Havana.
Proper recognition of Finlay's work was hampered by the rival claims of American, British, and other investigators into insect borne disease, at a time when national rivalries were intense. In particular, it was suggested that Finlay had borrowed his idea from Manson, who was investigating the transmission of filariasis at about the time that Finlay proposed mosquito borne transmission of yellow fever. True or not, Finlay took no steps to rebut the suggestion. As his obituary in the Journal of the American Medical Association of 28 August 1915 remarks: "He lacked the genius for self-exploitation and having established his doctrine modestly lived on with no thought of further recognition."

If that really was his intention then he succeeded. It was left to the generosity of the French, first to make the doctor from Cuba an officer of the Légion d'Honneur, which they did in 1908, and then, on 9 October 1934, to name a Paris street after him. In Britain Finlay, a cultured man with mainly Scottish antecedents, has, so far as I know, not been commemorated. Even the splendid frieze cut into the stonework of the London School of Hygiene and Tropical Medicine, where a whole football team (with reserves) of Finlay's distinguished contemporaries in the field of infectious and tropical diseases is named, omits him. Manson and Ross are given their due, but not Finlay. No wonder we merely think of Tannochbrae.

P P Mortimer, virologist, London

*In the 1960s there was a popular television serial in Britain called Dr Finlay's Casebook. It was set in a Scottish village general practice where Dr Finlay was the junior partner.

We welcome articles up to 600 words on topics such as A memorable patient, A paper that changed my practice, My most unfortunate mistake, or any other piece conveying instruction, pathos, or humour. If possible the article should be supplied on a disk. Permission is needed from the patient or a relative if an identifiable patient is referred to. We also welcome contributions for "Endpieces," consisting of quotations of up to 80 words (but most are considerably shorter) from any source, ancient or modern, which have appealed to the reader. 